\title{
THE INCORPORATION OF VIOLENCE BY WOMEN VIDEO ARTISTS
}

\author{
Teresa Veiga Furtado \\ Professor at the Department of Visual Arts and Design, University of Évora (UE) and researcher at \\ Centre of Art History and Artistic Research, (CHAIA/UE), and Centre of Research in Social \\ Sciences (CICS.NOVA), Faculty of Social Sciences and Humanities of Universidade Nova de \\ Lisboa (FCSH/UNL), PORTUGAL, tvf@uevora.pt
}

\begin{abstract}
This paper examines the way in which women video artists embodied violence in their video pieces as a strategy of critique of the patriarchal regime. Since the 1960s several generations of women artists used different strategies of self-harm or explored the physical and mental limits of their bodies to express the anguish of those who are excluded from the patriarchal society on sexist and/or racist grounds. Considering the guiding line that covers three fields - art, gender, and feminist social movements - as well as their key thinkers and scholars in Sociology, Fine Arts and the Humanities, we have built the object of study of this essay, namely, the relationship between women's video art focused on the body, violence and gender along with feminist social movements in the period ranging from 1967 to 2007, in a Western context. The methodology used had as its primary goal to create a link between the micro-sociological level of expressions, body gestures and behaviours in the videos and the macro-sociological level of broader, institutionalized social forces that are at the origin of inequalities, such as dimensions of gender and «race». This study concluded that at least since the 1960s there is the denunciation by women video artists of the general circumstances women live under, while enduring violence of various kinds, such as socio-cultural, psychological and sexual violence against women.
\end{abstract}

Keywords: Video art, feminist social movements, patriarchy, violence, gender, body, identity, selfdetermination.

\section{INTRODUCTION}

From the 1960s women artists were agents of a story in which, until then, they had not been represented, and claimed violence as a critical strategy of the phallocentrism in patriarchal social institutions. Over the course of several generations and up to the present day, they resorted to different strategies of self-harm and of exploring both the physical and mental limits of their bodies, namely in order to: symbolize the people's suffering in dictatorial and war contexts (Gina Pane, Abramovič Marina, Sigalit Landau, Ana Mendieta) and; express the anguish of those who are excluded from the patriarchal society on sexist (Mary 
Coble, Helena Almeida, Yoko Ono, Sanja Iveković, Pipilotti Rist, Katarzyna Kozyra, Pilar Albarracín), racist and/or ethnic grounds (Howardena Pindell, Tania Bruguera, Sigalit Landau, Tracey Rose). Their works constitute a metaphorical representation of the injuries inflicted upon people by wars, totalitarian governments and other patriarchal and power regimes, by reification, marginalization and the essentialisation of the other (any subject different from the Western middle class white man). In the late 1960s, the Vienna Actionists group was the first to use strategies of self-injury, shock, ritualized humiliation and exploitation of abject and body fluids in order to lead a bourgeois audience to witness and project itself into the experience of situations, experiences and behaviours possibly repressed and outright prohibited in people of their social status, thus promoting a cathartic experience resulting in the release of contained emotions and tensions. Many of these performances were recorded in the films of Kurt Kren and influenced the two succeeding generations of artists, including: Gina Pane in France; Marina Abramovič in former Yugoslavia; Stuart Brisley in the United Kingdom; and Nigel Rolfe in Ireland. All the performances of these artists were recorded on video (Elwes, 2005, p. 180). Women artists influenced by revolutionary anti-war, anti-racist and student movements as well as by feminist theories refused the silencing of their subjectivities and used their bodies as a medium to drive both critical and demanding political messages.

\section{THE OBJECT OF THE STUDY}

Against the backdrop of a guiding axis consisting of three vectors, namely, art, gender, and feminist social movements, as well as its main authors in various branches of Sociology, Visual Arts, and the Humanities, we built the object of study, focused on the relationship between women's video art, the gender dimension, the violence dimension and feminist social movements. In this sense, our central question is how to articulate, in a Western context, feminist debates with gender dimensions and the depictions of violence displayed in the video art of women focusing on their bodies, on identity and on self-determination, in the period from 1965 to 2007.

\section{RESEARCH STRATEGY AND METHODOLOGICAL TOOLS}

\subsection{Field of Observation}

The selection of the pieces that constitute our «corpus» of documents was carried out by means of a preliminary search of the videos that we watched in several European and North American exhibitions, on artists and video distributors' websites as well as on DVDs.

The selection of video pieces was made based on the following criteria:

1 - The work addresses issues centred on the body as a social place par excellence of construction of social difference between the subjects.

2 - The work uses critical strategies of social resistance from a feminist perspective, even if this perspective is not declared.

3 - The work displays a divergent narrative from the discourses of power being clearly focused on the personal experiences of the women video artists, and takes into account the specificity of each woman in time and space.

We decided to study exclusively the works themselves, with their finished and final appearance, that is, with the appearance the artists intended them to have when presenting to the public. To do so, in addition to a purely qualitative analysis, we used the content analysis technique that allowed us to encode the various relevant aspects of each of the videos and quantify them, for each and every one of the studied pieces, in order to make it easier to study and draw conclusions about them, in an objective, systematic and replicable fashion.

From an initial set of 50 videos it was found that the presence of violence as a social force clearly prevents the construction of herself as a subject, in the following 13 videos.

1 - Yoko Ono. Cut Piece. USA, 1965. Video, 9:10, b/w, sound; 2 - Ana Mendieta. Untitled (Chicken Piece). USA, 1972. Video, 6:23, colour, no sound; 3 - Marina Abramović. Rhythm 10, United Kingdom, 1973. Excerpt from the film Balkan Baroque, by Pierre Coulibeuf, France, 1999. $35 \mathrm{~mm}$ film, 63:00, colour, sound; 4 - Helena Almeida. Ouve-me. Portugal, 1979. Video, 4:50, p/b, no sound; 5 - Howardena Pindell. Free, White and 21. USA, 1980. Video, 12:15, colour, sound; 6 - Sanja Iveković. Osobni rezovi. Yugoslavia, 1982. Video, 3:35, colour, sound; 7 - Pipilotti Rist. I'm Not The Girl Who Misses Much. Switzerland, 1986. Video, 5:02, colour, sound; 8 - Katarzyna Kozyra. Olympia. Poland, 1996. Video, 12:40, colour, sound, and photographs. Installation: video and 3 photographs; 9 - Pilar Albarracín. La tortilla española. Spain, 1999. 
Video, 6:07, colour, sound; 10 - Tania Bruguera. El peso de la culpa. Cuba, 1999. Video, 4:52, colour, no sound; 11 - Sigalit Landau. Barbed Hula. Israel, 2000. Video, 1:52, colour, sound; 12 - Mary Coble. Session One. USA, 2007. Video, 5:00, colour, sound; 13 - Tracey Rose. Black Woman Walking. USA, 2007. Video, colour, sound, 8:03.

\subsection{Content analysis category: violence}

Here we shall deal with content analysis categories clearly associated with some kind of violence that is explicit and directly observable (Fig. 1). Even though these categories refer to forms of violence that are immediately and undoubtedly observable in their physical manifestations, in reality, there are other forms of non-physical violence, such as psychological violence, cultural violence, and other variants of non-material violence, which leave deep scars on individuals and whose reflections can sometimes be observed in the behaviour of the agents in the video pieces. These acts of violence do not flag, however, any of the possible options in the set of content analysis categories relating to violence, but, on the other hand, have a clear expression within the categories of text or, alternatively, just in the narrative of the video piece. This is exactly what happens, for example, with Helena Almeida's video, Ouve-me (Listen to Me), 1979, a work that depicts a situation of both oppressive and extreme violence, without any acts of violence being at any time directly shown. In fact, violence is only displayed in the text and in the very narrative of this video piece.

\subsubsection{Third party violence against a woman.}

Use of violence, physical or otherwise, of third party against a woman.

\subsubsection{Self-inflicted Violence.}

Use of violence, physical or otherwise, of a woman against herself. In this case the perpetrator and the victim are one and the same person. In our study, in this regard, we only encounter acts of self-harm.

\subsubsection{Woman's or third party violence against an object or animal.}

The use or allusion to act of violence, physical or otherwise, exercised by a woman or third party against an object or animal.

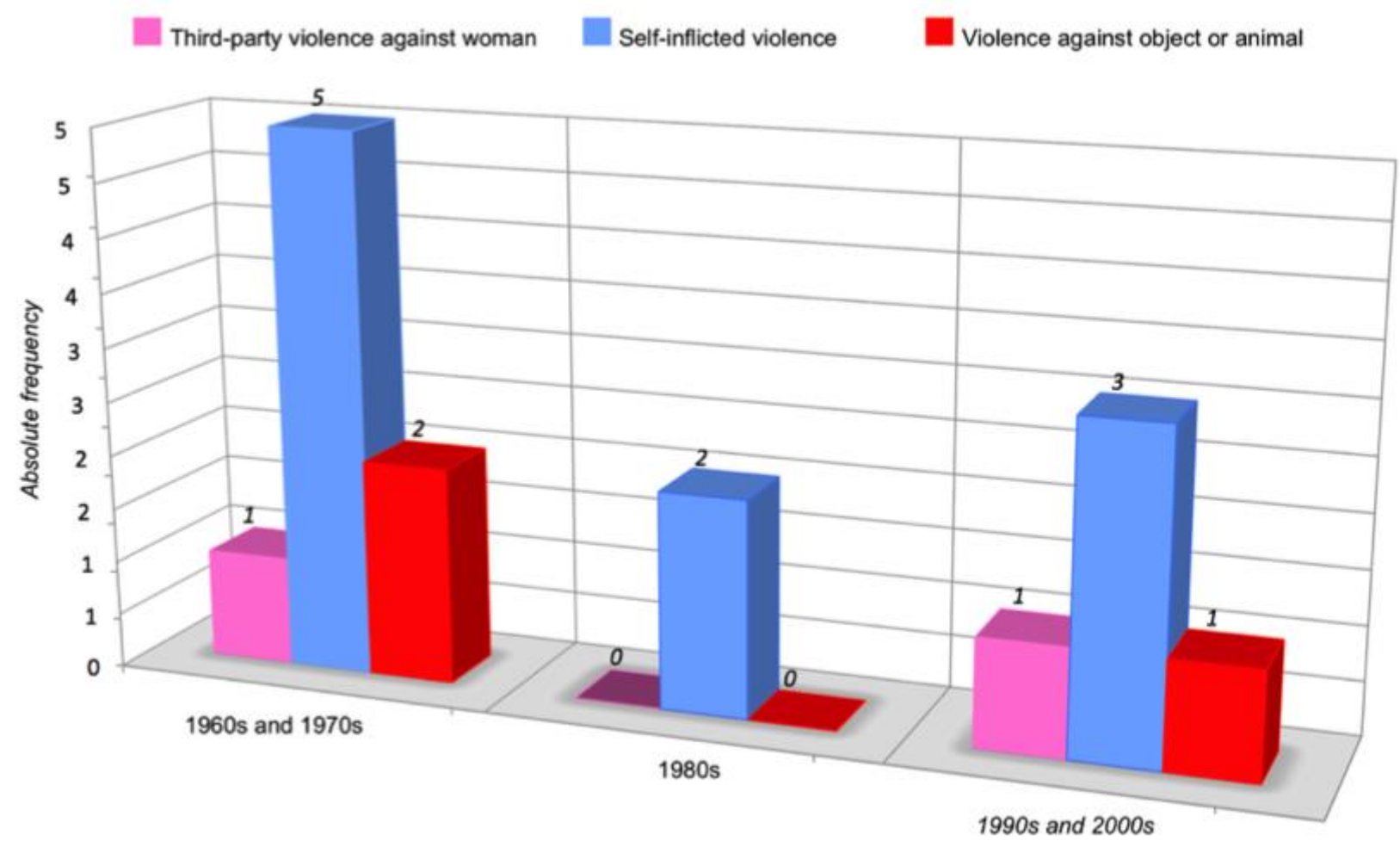

Fig. 1. Content Analysis Categories: Violence from the 1960s to the 2000 s in a selection of 46 videos (N). Selection of 46 videos distributed by decade as follows: 2 in the 1960s, 17 in the 1970s, 11 in the 1980s and 10 in the 2000s. Source: Furtado, Teresa, 2012, study made from the analysis of 50 videos. 


\subsection{Critical Evaluation of Sources}

During the elaboration of analysis charts according to a temporal sequence, given the fact that there are only two videos in the 1960s, and so as not to skew the results, we have chosen to combine the 1960s with the 1970s. The 1960s are years of great transformations, but only in 1965, when video emerged, did women begin to use it. That is the reason why the reduced number of videos in the field of observation regarding this decade it is perfectly understandable. In the 1960s, the hippie, civil rights and anti-war movements, exist in the US, while the workers' movements and the demonstrations of May 68 students, among others, occur in Europe. All these great socio-cultural transformations of Western society emerge in the 1960s and will feed Feminism's Second Wave especially during the 1970s, and it is therefore understandable that the explosion of video art made by women artists has also taken place in this decade. We decided to isolate the videos from the 1980s, as we see this decade as a period of transition, during which there is criticism in relation to the representation of the body and sexuality, a criticism that is viewed with suspicion by a part of the feminist movement, and finally to combine the 1990s and 2000s. To sum up, we considered three time periods: an initial phase of two decades of emergency and expansion of the video (the 1960s and 1970s); a decade after the widespread deployment of video, which is an intermediate period and a period of change (the 1980s), as well as; a final phase, corresponding to the ripening of the «medium» during the last two decades (the 1990s and 2000s).

\section{THE SELF-MUTILATORY PERFORMANCES OF THE 1960s AND 1970s}

The analysis of the feminist collective awakening of the 1960s, allows us to characterize it as traumatic because the most powerful feminist art from this period was devoted to the representation of pain and trauma (Phelan; Reckitt, 2001, p. 44). Often, feminist art has aimed at exploring the consequences of specific forms of violence that women experience in a world ruled by men, as is evidenced by the work of Suzanne Lacy and Leslie Labowitz, Gina Pane, Marina Abramovič and Orlan, among others. In the 1970s several artists conducted self-mutilatory performances in which the body spoke a non-verbal discourse which was understood as language, support, instrument and foremost as an extraordinary knowledge and communication tool, used in sharing and fellowship with other people, appealing for empathy, compassion and reflection. When Gina Pane self-mutilated herself, as would do Sonia Knox and Orlan later, she turned literal the symbolic wounds that had been made by Hannah Wilke in her own body. These self-mutilatory rituals converted the flesh of the artist into the flesh of the world, her body into the social body, and were visual metaphors of the violence perpetrated by power against individuals and thus materializing, displaying and ultimately making visible an invisible wound. The video Cut Piece (USA, 1965), by artist Yoko Ono (Japan, 1933), is the documentation of a performance in which the artist, sitting on a stage, invites viewers to cut her clothes off with the aid of a pair of scissors. This performance, which is the result of a participatory inter-relation between the spectator and the artist, deals with topics related to gender, voyeurism, aggression, sexual subordination of women, rape and the vulnerability of personal body space. Throughout the performance, Ono becomes the agent of her own reification because, even though she selects the role of «Servant» when choosing to be the victim of a violent act, namely, the cutting pieces of her clothes off by the spectators, she simultaneously plays a positive role, since she forces the viewer to become aware of their role as «Master», in the sense of employer and proprietor, while being an agent of an oppressive act and therefore complicit in the construction of the woman as the Other (Jones, 2009, p. 291).

The theme of violence against women is discussed, in symbolic form, by the artist Ana Mendieta (Cuba, 1948 - USA, 1985) in the video Untitled (Chicken Piece) (USA, 1972) and is part of a series of performances by this artist made in 1972 and 1973 on this subject. This performance, held at the University of lowa, where she was studying at the time, was the first of a series of works that evoke the social violence exerted against women and, on the one hand, inspired by the «actions» of Vienna Actionists representing male virility, while, on the other, evoke the sacrifice and violence existing in the rituals of the ancient Mexican civilizations and in Cuban Voodoo (Centre Pompidou et l'Ina). In the performance Rhythm 10 (United Kingdom, 1973), Marina Abramovič runs gestural rituals with knives, for about 1 hour, evoking a traditional game of Russian origin. Often during her performances the artist explores extreme physical and psychological situations, putting herself in circumstances of great body and mental demand resulting in exhaustion that render the functioning of rational thinking impossible and nullify all cultural mechanisms. In this video, Abramovič performs a dual transgression of the borders of femininity, as this is traditionally understood, when looking for, on the one hand, to achieve high levels of endurance to pain, which is habitually associated with the male gender, and on the other hand, when handling a knife that is in itself symbolically a masculine slitting tool. According to Bourdieu, the knife, as well as the act of cutting and exercising violence, are typically masculine (Bourdieu, 1999, p. 23, 63). In the video Ouve-me (Listen to Me) (Portugal, 1979), the body/canvas of artist Helena Almeida (Portugal, 1934) searches incessantly to gain visibility and, as the title suggests, to be heard by the 
viewer who is inquired by the artist. In this video violence is suggested by the action of the artist who seems to be suffocating and prevented from talking behind the canvas, which, in our opinion, is a way of first and foremost symbolically evoking some kind of cultural violence that results from a system of masculine domination. Almeida, in a metaphorical way, draws attention to the cultural limitations, both physical and psychological, imposed on women, by using different gestures, like the writing/scratching «Ouve-me» (Listen to $\mathrm{Me}$ ) on the canvas metamorphosed into body.

\section{VIOLENCE, IRONY AND HUMOUR INSTRUMENTS IN THE 1980s}

In the early 1980s, the female artists from the 1960s and 1970s were criticized by feminists under the influence of psychoanalysis and the post-structuralism, as being essentialist. These feminist authors argued that bodily depictions made by women artists constituted a trap for women, to the extent that they could be easily made suitable for male reification, and also criticized the emphasis on personal history and of the individualistic nature of their work. Nevertheless, chiefly from the mid-1980s, these same female feminist authors were also the subject of criticism for their didactic and moral pretensions and excessive emotional containment. And from that time to the present there has been a resurfacing of irony and pleasure, as well as the integration of images of popular culture in women's art (Phelan, 2001, p. 164-168). One such example can be found in the video I'm Not The Girl Who Misses Much (1986, Switzerland) by Pipilotti Rist (Switzerland, 1962). In this work, the artist dances and frantically sings a song of John Lennon «Happinness is a Warm Gun», 1968, adopting a humorous style overstating the role of object pop music assigns to women, relegating them to the place of the Other. The alternation between the speed and the rewind of both the tracks of sound and image breaks their original connection, transforming their representation in an icon of the absurd. There is a double displacement, both of the body and of the voice, which creates an effect of distance in regard to the image and seeks to reveal the artificial nature of female representations in pop culture. The artist adopts an attitude in which she expresses violence against herself in as much as she represents her own person as dysfunctional and singing incorrectly and out of sync, invoking in the observer both mockery and commiseration regarding her chaotic makeup, clumsy dance and clothes in disarray that do not cover her bare breasts.

The artist, activist and African American curator Howardeena Pindell (USA, 1941), in her video Free, White and 21, (USA, 1980) covers situations where, throughout her life, she was the target of racism and sexism. In that video, Pindell emerges both as the Negro narrator and as white Western woman, wearing a blonde wig and sunglasses. The black woman, represented by the artist herself, shall progressively, throughout the video, suffer a symbolic metamorphosis into a white woman, by binding her head with white gauze bandages so as to keep the head totally covered and hidden from our eyes. The words of the Negro narrator consist of autobiographical accounts of the artist's life, about when she was subjected to racist and sexist prejudices, while the white character responds, outraged, to those stories, accusing the African American woman of being delusional and ungrateful. The artist uses severe criticism regarding the silence that black women are forced into within different social spheres, as they are forced very early in life to be aware of the strong barriers that separate the world of white people from the world of black people. In the video Osobni rezovi Personal Cuts (Yugoslavia, 1982), Sanja Iveković (Croatia, 1949) focuses on the power mass media have over people in general and the power they have over sociocultural discrimination against women, in particular. This type of discrimination, in the words of Manuel Lisboa, refers to «images or phrases associated with the condition of being a woman on TV, newspapers, radio and/or advertising " (Lisboa, 2009, p. 42) as well as to other discriminating social attitudes, values and norms, and is regarded as an act of violence against women, which makes them feel both wronged and aggrieved. According to the author, there is a growing perception at present that: «(...) there are images and phrases conveyed by the media/advertising and the school that can affect the image of women and strengthen the values of gender inequality. This may be an indicator of greater awareness of the importance of that dimension and, therefore, a favourable space for the intervention in the field of prevention when it comes to gender equality " (Lisboa, 2009, p. 116). The artist intercuts images of a close-up of her head, completely covered by a black sock that she carves up with scissors throughout the video, with advertisements and images of historical documentary footage about Yugoslavia, taken from the program «The History of Yugoslavia» which ran in the Yugoslav State television. Iveković alternates each stroke of scissors with the television images that highlight gender roles of male and female as frames of soldiers, football players, women in fashion shows, shop windows for women's shoes, female manufacturing workers and female administrative workers, for example. 


\title{
6 VIOLENCE AND INTERSECTIONALITY IN THE DIMENSIONS OF AGE, CLASS, SEXUAL ORIENTATION AND «RACE», DURING THE 1990s AND 2000s
}

On the subject of men's violence against women, Giddens argues:

\begin{abstract}
"Modern societies have a covert emotional history, yet to be fully drawn into the open. It is a history of the sexual pursuits of men, kept separate from their public selves. The sexual control of women by men is much more than an incidental features of modern social life. As that control starts to break down, we see the compulsive character of male sexuality more plainly revealed - and this declining control also generates a rising tide of male violence towards women. At the moment, an emotional abyss has opened up between the sexes, and one cannot say with any certainty how far it will be bridged» (Giddens, 2008, p. 2). Regarding this issue Lisboa maintains: «In recent decades Western societies have beeen experiencing a transition phase within the public gender regime towards greater gender equality. In modern societies there is a greater awareness and reflexivity about gender inequalities than in traditional societies, however, this did not eliminate the conflict between the genders and sometimes did even contribute to an increased tension between them» (Lisboa, 2006, p.53-54). The issue of violence in the sphere of private life is discussed symbolically, by artist Pilar Albarracín (Spain, 1968), in the video Tortilla a la española (Spain, 1999). Throughout the video, the artist dressed in red, inside an industrial kitchen, an environment that evokes a television culinary programme, scrambles several eggs vigorously in a glass cup, adding pieces of fabric directly cut from her dress to the mixture. It seems to us that, in the course of the video, Albarracín satirizes the role of the unselfish and disciplined housewife, which literally cuts up her own clothes to use as an ingredient in the making of the perfect tortilla.
\end{abstract}

In the analysis of the phenomena of gender-based violence against women other dimensions should not be neglected, such as class, sexual orientation or «race», among others, that make each biography a specific and individual case. In recent decades, the concept of intersectionality has been growing in importance, in an attempt to understand the differentiated experience not just of poverty but also of social life as a whole (Giddens; Sutton, 2014, p. 99). The installation The Olympia (Poland, 1996) by artist Katarzyna Kozyra (Poland, 1963) deals with the social pressure exerted on sick bodies, and also with coercion and sociocultural discrimination against women, achieved by means of various discourses, namely that of the fine arts. This installation consists of a large format photographic triptych and a video. The photographic triptych is composed of three images: one of the photographs represents the artist, in a setting that evokes the painting Olympia by Manet, in the role of Olympia; another shows her in a mobile hospital bed; and the last represents an elderly woman in the role of Olympia. At first, her figure evokes the character of Manet's painting Olympia, however, in a second reading, we realize the fetishist body with voluptuous forms of Olympia was replaced by the lean and sick body of Kozyra, devoid of hair, eyebrows and eyelashes, which transgresses the protocols of the female nude in the history of art, not respecting the boundaries and traditional standards. So, the sick body of Kozyra, as well as the elderly woman's, both naked and represented in the pictures of this installation, are bodies which the artist uses, intentionally, to transgress cultural protocols of the female nude. In the documentary video Black Woman Walking (USA, 2007), the artist Tracey Rose (South Africa, 1974), records experiences of sexual harassment and physical violence suffered by black women, and practiced by black men, when these women move through the streets of U.S. cities in their daily lives. This type of violence against women, namely harassment in the streets and indecent sexual exposure, is often marginalized by policies and practices to combat violence against women (Kelly; Lovett, 2005, p. 6-7). Rose, in the course of the video, gives voice to different black women, so that this doesn't become a monolithic and one-dimensional documentary. This video is dedicated to a young black 16-year-old Adilah Gaither, shot dead for refusing to provide her phone number to a young black man, when she was approached by him at a bus stop.

In the new millennium there were several artists, such as Mary Coble, Tania Bruguera and Sigalit Landau, who rediscovered the strategies of activist artists of the 1960s and 1970s. In an indirect metaphorical and corporeal fashion, Coble, Landau and Bruguera, adopting the self-mutilatory and self-suffering strategies, which can be witnessed, for example, in the works of Gina Pane about the Vietnam war, evoke contemporary war situations, in particular the Israeli-Palestinian conflict and also to Cuba of Castro and its dictatorial aspects (Bajac, 2009, p. 49). The video by the Cuban artist Tania Bruguera (Cuba, 1968) El peso de la culpa (Cuba, 1999), originates from a series of performances entitled Memorias de la postguerra, and features in common with Untitled (Chicken Piece) by Mendieta, a feminist perspective, both political and poetical, inspired by the African Cuban culture and religion, the use of a dead animal and the artist's own body. Bruguera's performance was inspired by a story transmitted orally over a group of Cuban indigenous people, that when faced with the Spanish colonizers in 1492, committed collective suicide as defensive strategy of self-annihilation (Muñoz, 2009). The artist Sigalit Landau (Israel, 1969) in her video Barbed Hula 
(Israel, 2001), in the same way as Abramovič, transgresses gender standards both through the handling of a sharp object and through her resistance to the pain she inflicts upon herself. During the performance, the artist uses a ring of barbed wire with $90 \mathrm{~cm}$ in diameter rotating around her waist. The barbed wire ring evokes the image of a symbolic territorial border which is pushed outside its original limits generating a situation of conflict, here expressed, in a literally penetrating way, by the wounds and cuts in the skin.

Homosexuality has been stigmatized in many countries around the world, and homophobia a term coined in the 1960s, regarding attitudes and aversion or hatred towards homosexuals and their lifestyles. Homophobia is a form of prejudice that translates into explicit actions of hostility and violence and various forms of verbal abuse. (Giddens; Sutton, 2014, p. 169). The video piece that is analysed below, deals with the way certain social forces create institutionalized discrimination processes, that are "naturalized» with regard to sexual orientation, and have huge consequences in social life, preventing, for example, the subjectification of individuals.

\section{CASE STUDY: MARY COBLE}

The artist Mary Coble (USA, 1978) often uses the body in her work to ask questions about the construction of sexual difference - in particular about the phenomena of inequality resulting from sexual orientation and gender. Sometimes she hurts her own body in order to symbolize the physical and mental suffering that individuals who do not fall within the heterosexual norms - as gay, lesbian, bisexual, transgender, intersex and transgender people - experience by being socially segregated. Coble challenges the audience to reflect on the phenomenon of discrimination, such as homophobia. Her video Session One (USA, 2007) shows pictures of her arm suffering seizures caused by electric shock, during a performance. Having been introduced in 1938, by Ugo Cerletti, in Italy, electroconvulsive therapy was since then used in the treatment of severe mental illnesses and also in the attempt to cure homosexuality, assuming that this would be a pathology resulting from neuro-biochemical deficiencies, which could, therefore, be cured. The psychiatric technique of electroconvulsive therapy was used in the U.S.A. since the late 1930s until the early 1970s (Berger, 2007), in clinics and hospitals, having been applied to homosexuals, with the declared aim of changing their sexual orientation. Issues relating to the artist's sexual identity and homosexuality determined the way of artistic expression used by Coble in this video piece. Showing the pain experienced by a subject is also a way of making explicit the suffering resulting from the rejection of a non-heteronormative sexuality and of the repression imposed on someone who is considered deviant. With the materialization of this wound and this torment, the artist seeks empathy from an indifferent audience that may even be hostile to individuals of non-heterosexual orientation and tries to create a shared emotional space. In this piece, the artist introduces the image of her body in suffering, setting out a social and political activism with a fierce criticism of the collective institutions, medical in this case, condemning the dehumanization of one group of society. This extreme act emphasizes the role of violence in the lives of homosexuals and confronts the viewer with the passivity and the callousness with which these issues are often dealt with in everyday life.

Human beings are constantly making value judgments within social gatherings on a wide variety of aspects and the term "deviant», or perverse, is applied by a particular group of individuals to others who do not conform to the dominant regulatory standard defined in the collective context they happen to live in (Molotch, 2010). "Deviance», according to the sociological perspective, in particular that of symbolic interactionism, is understood not as an attribute, an essence of people, but, first and foremost, as a process set in motion in a specific social context. This process requires the existence, on the one hand, of individuals who are not supporters of the standards, mechanisms, operating modes of a given social organisation and, on the other hand, the existence of structures and people who trigger the labelling mechanism of «deviation». It should be noted that this process takes different forms depending on the historical periods and their forms of social organization. Often, people who do not conform to the standards in force are classified as «deviants», that is, as having something different, essential, psychologically or physiologically. The labelling process operates as a stigma that can be carried out informally, the interaction of the day-by-day, or formally, for example, when an individual is classified by psychiatrists as mentally ill. So, in the colonial period, it was thought that Indians had no soul and that witches had been possessed by the devil and the penalty for these people was punishment, isolation, or even death (Molotch, 2010). The American Psychiatric Association classified homosexuality as a mental illness up to the 1970s. From that time onwards, homosexuality was removed from the list of clinical deviant behaviours and started to be treated as a normal behaviour. In previous years homosexuality had been regarded as totally unacceptable and illegal behaviour, the Devil's own, often leading to the death of its practitioners, however, today it is an accepted phenomenon in many Western countries. According to Durkheim, people differ from each other by the imposition of standards, limits and boundaries that should not be violated, and the identification of an individual with a particular social group is intrinsically linked to its demarcation in relation to another. Similarly, the identification of rules, transgressions 
and the borders that demarcate any society allows us to understand the mechanisms through which it remains cohesive, and gives individuals a common identity. In various historical periods, homosexuality was cause for social concern, being understood as an attribute of a certain type of individuals, which should be labelled «deviant» and suffer a set of corrective measures for doing something forbidden (Molotch, 2010).

Coble's video is deals with a supposed medical treatment to cure homosexuality. That being the case, during the performance Aversion (USA, 2007) from which resulted, among other works, the video Session One, the artist, dressed in white, began by sitting in a reclining Chair, placed inside a gallery, and a female assistant connected her to an electroshock machine by means of two electrodes attached to her left arm. On a screen placed in front of Coble, a series of slides depicting almost naked women and men was shown. Whenever a picture of a woman was seen, the assistant discharged electricity into Coble's arm. The artist recreates thus the psychiatric treatment for about thirty minutes. In another of the videos resulting from this project, titled Aversion Recounted (USA, 2007), people who have suffered this therapy narrate their experiences (although it is not really clear whether these are genuine or staged interviews). For Coble, attempting to cure people with this and other therapies in the past is absurd, since these therapies served exclusively for physical and mental damage in individuals undergoing such operations. The artist says:

«I don't try to explain the horrors of prejudice. I don't think that is something that I understand enough or am able to fully wrap my mind around. Using my body, many times as a metaphor or site for questioning, I do hope my art can help bring these issues to the forefront of people's attention. The awareness and the perspective that I offer people through my work can make a difference in our world. If one person sees this work and is affected then I count that as a success» (McFarland, 2009).

For Coble her self-mutilatory performances don't have as motivation the experience of pain itself, but they are the only way the artist found to effectively express her ideas about the social marginalization or social exclusion. Coble video can be considered as a beneficiary of the work of other women artists, especially of Gina Pane. Less mentioned by art criticism is the "queer» dimension of the work of Pane and how issues linked to the artists' sexual identity and homosexuality determined the mode of artistic expression. This being one motivation present in all her work, it is particularly evident in two actions, the Azione Sentimentale, held in Milan in 1973, and the Action Mélancolique $2 \times 2 \times 2$, which took place in Naples in 1974 and was documented on video. The first of these actions, the most celebrated of the artist, is aimed exclusively at a female audience and deals with an affective context of its own, constituting a proclamation of love between women. Beyond the famous scene of the handling of a bouquet of roses, thorns carved in the forearm and the cut with a razor blade in the Palm of her hand, resulting in a new rose, composed by forearm - evoking the stem - and the bloody hand of the artist - in which the blood draws the petals - offered to the female audience as a confession of love, it is heard, during the action, the voice of two women, one French and one Italian, reading love letters they have exchanged between themselves. Action Mélancolique $2 \times 2 \times 2$ deals with gay rights as well as love stories, and presents three couples on stage: two women, two men and a woman and a man, each couple holding a bouquet of roses. Pane stated that by putting gay couples next to a heterosexual couple onstage, she intended to remove and reject any pathological associations from the story, creating a shared emotional space (Beckman, 2007).

\section{CONCLUSION}

Since the 1960s up to the present that female artists offer the general public and, in particular, physically or psychologically traumatized people, who happen to be unable to verbally express their pain, the possibility to live a cathartic experience of soothing and comforting effect. The extreme acts of self-mutilation, practiced by women artists, emphasize the role of violence in modern everyday life and question the viewers about the passivity and vulnerability that are internalized when it comes to these themes in their quotidian lives. The violent artistic practices were a way to cause pain to the audience and constituted both a representation and resubmission - or re-presentation - of the anguish that female artists felt when faced with social constraints. In the new millennium, there were several women artists who rediscovered the strategies of activist artists of the 1960s and 1970s and, indirectly, metaphoricaly and corporealy, adopted self-mutilatory and self-inflicting suffering strategies which had been used with regard to the Vietnam war, and evoked contemporary war situations. Self-mutilation rituals seek to symbolically turn the bodies of women artists into the bodies of spectators, thus trying to convert the bodies of female authors into the social body, and constituting, in this way, visual metaphors of violence by power against the people.

At present, in spite of progress in women's rights and citizenship, such as access to justice, to education, to work, to leisure, to political and civil participation, and to freedom of movement, as sexual control of women by men begins to decline the compulsive nature of male sexuality in the form of violence becomes apparent. Many women are victims of various types of violence worldwide, carried out by men - whistling on the street, 
obscene phone calls, pornographic images, stalking, sexual harassment, assault, sex under duress, rape, murder or even genocide -, framed by various systems of exclusion and inequality such as class, race, sexual orientation, physical disability, among others that intersect with that of gender. The documentary format is sometimes adopted by female artists as a way of promoting women's awareness, thus recovering practices of the early feminist groups. Feminine artists use techniques of approach and treatment of women in interviews that translate into a political analysis of the subjective experiences that the mass media rarely allow. In addition, they tell stories with a political objective, such as the promotion of active resistance to unwanted sexual affairs, as well as the refusal of male privilege affirmation. Sociocultural violence against women through images or phrases relating to the status of women in mass media is also addressed in their work.

\section{ACKNOWLEDGEMENTS}

This research was financially supported by: CHAIA - Centre of Art History and Artistic Research, University of Évora; FCT - Foundation of Science and Technology, Portugal.

\section{REFERENCE LIST}

"Ana Mendieta". [Online] [Consult. 2009-01-01]. Coproduction est une coédition du Centre Pompidou et de I'Institut national de l'audiovisuel. http://www.ina.fr/fresques/ellescentrepompidou/Html/credits.php.

Bajac, Q. (2009). "Feu à volonté". In elles @ centrepompidou. Artistes femmes dans la collection du Musée national d'art moderne, Centre de création industrielle (2009) [Cat.]. Paris: Centre Pompidou.

Beckman, R. (2007). "Aversion: the Jolt Of an Experience". [Online] [Consult. 2009-03-10]. The Washington Post. (24-05-2007). Connersmith - Mary Coble - Selected Press.

http://www.connercontemporary.com/artists/mary-coble/? view = press.

Berger, A. (2007). "An Electrifying Assimilation" [Online] [Consult. 2009-10-09]. express, a publication of The Washington Post. Connersmith - Mary Coble - Selected Press. http://www.connercontemporary.com/artists/mary-coble/? view = press.

Bourdieu, P. (1999). A Dominação Masculina. Oeiras: Celta Editora.

Elwes, C. (2005). Video Art, a Guided Tour. London: I.B. Tauris.

Giddens, A. (2008 [1992]). The Transformation of Intimacy: Sexuality, Love and Eroticism in Modern Societies. Oxford: Polity Press.

Giddens; A.; Sutton, P. W. (2014). Essential Concepts in Sociology. Cambridge: Polity Press.

Jones, A. (2009). Genital Panic. "La menace des corps féministes et le paraféminisme". In elles @ centrepompidou. Artistes femmes dans la collection du Musée national d'art moderne, Centre de création industrielle. (2009) [Cat.]. Paris: Centre Pompidou.

Kelly, L.; Lovett, J. (2005). "What a Waste: The Case for an Integrated Violence Against Women Strategy". [Online]. [Consult. 2011-04-01]. UK: Amnesty International UK (AIUK)/Women's National Commission (WNC), http://www.endviolenceagainstwomen.org.uk/data/files/resources/18/what-a-waste-2004.pdf

Lisboa, M. (2006). "Capítulo 3: Contexto social da vitimação". In Lisboa, M. (coord.) [et al.] (2006). Prevenir ou remediar: Os custos sociais e económicos da violência contra as mulheres. Lisboa: Edições Colibri/SociNova.

Lisboa, M. (2009). "Capítulo 3: A violência contra as mulheres numa perspectiva comparativa"; "Conclusão". In Lisboa, M. (coord.) (2009). Violência e Género - Inquérito Nacional sobre a Violência Exercida contra Mulheres e Homens". Lisboa: Comissão para a Cidadania e Igualdade de Género.

McFarland, P. M. (2009). "mary coble / interviewed by paulina mowicka mcfarland" [Online] [Consult. 200910-20]. ArtXX. Radical Arts Magazine. Issue 2. (9/15/2009). Connersmith. - Mary Coble - Selected Press. http://www.connercontemporary.com/artists/mary-coble/? view = press.

Molotch, H. (2010). Lecture 10: "Deviance" (so-called) Part II [Online Video] [Consult. 2011-01-01]. Intro to Sociology. New York: New York University. http://www.nyu.edu/academics/openeducation/coursesnew/intro-sociology.html. 
Muñoz, J. Performing Greater Cuba: Tania Bruguera and the Burden of Guilt. [Online] [Consult. 2009-05-23]. Threads of the Woven Maze. Holy Terrors: Latin American Women Perform - Google Books. http://books.google.pt/books?id=I5glK7DPAzMC\&pg=PA401\&lpg=PA401\&dq=jose+munoz+performin g+greater+cuba+tania+bruguera+and+burden+of+guilt

Phelan, P (2001) "Survey", in Reckitt, H; Phelan, (eds.) (2001). Art and Feminism. London: Phaidon Press. 